\title{
A Preliminary Geochemical and Isotopic Appraisal of Sea Water Intrusion in the Fushë Kuqe Aquifer (Northwestern Albania)
}

\author{
Sabina Cenameri ${ }^{1}$ and Arjan Beqiraj ${ }^{2}$ \\ 1. Ministry of Tourism and Environment, Blv. Deshmoret e Kombit, No. 1, Tirana 1001, Albania \\ 2. Faculty of Geology and Mining, Str. "Elbasani", Tirana 1020, Albania
}

\begin{abstract}
The Fushë Kuqe costal aquifer is a typical confined alluvial aquifer. The aquifer medium consists of sand-gravel and silt-clay layers intercalation which gave it a multilayer character. The aquifer recharge occurs mainly by water infiltration from the Rver Mat in the North, and from River Droja in the South. The water flow direction is from northeast to southwest and from southeast to northwest, discharging to the Adriatic Sea. Based on the chloride and TDS (Total Solids Dissolved) content in groundwater, an advancement of sea water intrusion into aquifer was evidenced. The direction of sea water wedge is from coastal south-western sectors towards the north-eastern ones. Sample No. 6, 8, 9 and 10 show chloride concentrations over $100 \mathrm{mg} / \mathrm{L}$ and Na/Cl ratios less than 0.86 implying that the groundwater is impacted by sea water intrusion. SR (Simpson Ratio) values of 1.15 and 1.09 for water sample No. 8 and 10 are indications of a slight seawater influence, while groundwater of sample no. 6 and 9 have SR values of 6.02 and 12.35 which are typical for a highly contamination by sea water. All the points of sampled groundwater fall above the GMWL, indicating that they have suffered a preliminary evaporation before entering the aquifer, likely in the hydropower lakes of Ulza and Shkopet upstream the River Mat course. Despite the narrow range of $\delta^{18} \mathrm{O}$ and $\delta^{2} \mathrm{H}$ values $(-6.80 \%$ to $-8.00 \%$ and $-54.00 \%$ o to $42.00 \%$, respectively), the points of sample No. $6,8,9,10$ fall on the fresh water-seawater mixing line, indicating the influence of the seawater intrusion.
\end{abstract}

Key words: Aquifer, groundwater, seawater intrusion, geochemistry, Fushë Kuqe, Albania.

\section{Introduction}

The Fushë Kuqe costal aquifer extends along the southern side of River Mat fan and represents a typical confined alluvial aquifer located in Western Albania (Fig. 1). It consists of discontinuous gravel-sand and silt-clay layers intercalations giving it a multilayer character. The thickness of aquifer gravel-sand formations ranges from 5-10 $\mathrm{m}$ in the east to $180-200$ $\mathrm{m}$ in the west, whereas the thickness of impermeable silt-clay cover ranges from 0.0 at the river outlet to $30-40 \mathrm{~m}$ in the west [1].

The aquifer is mainly recharged by water infiltration from the River Mat in its outlet into the plain [2]. The groundwater flows from northeast to southwest and

Corresponding author: Arjan Beqiraj, professor, Ph.D., main research fields: hydrochemistry and environmental sciences. discharges to the bottom of Adriatic Sea. In the western area of the aquifer extension, where it changes to completely confined conditions, the piezometric head varies and reaches up to $3 \mathrm{~m}$ a.s.1. [2].

The hydraulic parameters of the aquifer vary going from north-northeastern to south-southwestern sectors. Thus, the transmissibility of the aquifer is high $(4,000$ to $8,000 \mathrm{~m}^{2} / \mathrm{d}$ ) along southern side of River Mat and gradually decreases to about $500-1,000 \mathrm{~m}^{2} / \mathrm{d}$ along northern side of River Ishem [3].

Seawater intrusion, which is a natural process that occurs in almost all coastal aquifers, consists of salty water inflow from the sea towards freshwater aquifers and flowing inland. The seawater-fresh water interaction was firstly formulated by Baydon-Ghyben (1888, 1889) and Herzberg (1901) which is referred as the Ghyben-Herzberg formulation. Under natural, undisturbed conditions, a seaward hydraulic gradient 
exists in the aquifer with freshwater discharging into the sea [4]. The heavier saltwater flows in from the sea and a wedge-shaped body of saltwater develops beneath the lighter freshwater, with the freshwater thickness decreasing from the wedge towards the sea.

The presence of sea water intrusion in Fushë Kuqe aquifer is reported by different authors [5-12], whose opinions have some differences regarding salt water origin along the western coastal area of the aquifer.

\section{Material and Methods}

Eleven groundwater samples were taken for both chemical and isotopic analysis of H-2 and O-18. Three other surface water samples were taken: one from River Mat, one from a karst spring in Laci town and one from the Adriatic Sea. The locations of all samples are shown in Fig. 1.

The groundwater was directly sampled from the artesian wells, while in semi-artesian ones it was either pumped or using the SEBA Liquid Sampler KLL-S. The water samples taken from artesian wells represent a mixture of groundwater that drains into the well from different aquifer layers. Field measurements of $\mathrm{pH}$ and temperature were taken immediately upon collection of the sample. $\mathrm{pH}$ and temperature were measured using a Hanna HI 9023 temperature-compensated pH meter. The water samples are taken in polyethylene bottles, with volume of $1.5 \mathrm{~L}$ and $50 \mathrm{~mL}$ (double capped), for chemical and isotopic analysis, respectively.

Chemical analysis is made in Chemical Laboratory of the Geological Survey of Albania, Tirana. $\mathrm{Ca}^{2+}$ and $\mathrm{Mg}^{2+}$, hardness and $\mathrm{HCO}_{3}{ }^{-}$were analyzed via titration; $\mathrm{Cl}^{-}$and $\mathrm{SO}_{4}{ }^{2-}$ by photometry; $\mathrm{pH}$ and electric conductivity by electrochemistry; TDS (Total Solids Dissolved) was calculated after electric conductivity values; Fetot, $\mathrm{Na}^{+}$and $\mathrm{K}^{+}$were analyzed in Atomic Absorption Spectrophotomete "PERKIN ELMER" in both flame technic 400 AANALYST and 900 AA model with graphite furnace.

Isotopic analysis of $\mathrm{H}-2$ and $\mathrm{O}-18$ is made at the Chemical-physical Laboratory of Institute of
Geoscinces and Georesources, Pisa, Italy. Deuterium was directly measured in the vapour phase of the water molecule, the instrument used was Liquid Water Isotope Analyzer (LWIA) produced by Los Gatos Research (LGR) which is based on technic of CRDS (Cavity Ringdown Spectroscopy). Reference standard: SMOW (Standard Mean Ocean Water) (Craig, 1961). Oxygen-18 was determined through isotopic equilibration of water with $\mathrm{CO}_{2}$ at $25{ }^{\circ} \mathrm{C}$ and isotopic analysis of $\mathrm{CO}_{2}$ by mass spectrometer type MAT 252 produced by Finningan. Reference standard: SMOW (Standard Mean Ocean Water) (Craig, 1961).

\section{Hydrogeological Setting}

Fushë Kuqe aquifer is located in north-west Albania and it is an important area of Tirana-Lezha basin which represents a depression formed during Quaternary thanks to earth sinking against raising up regime of the eastern sectors where older (Paleogene flysch and Cretaceous limestone) geological formations outcrop (Fig. 1). The depression was successively filled up with sediments which mostly are of alluvial origin but to a less extent present marshy and marine sediments that compose the uppermost part of the Quaternary section. The thickness of Quaternary section ranges from about $60-80 \mathrm{~m}$ in southern (Shllinza) area up to about $200 \mathrm{~m}$ in the Patok area [2].

The costal aquifer of Fushë Kuqe is an alluvial aquifer that occurs under confined conditions. Its medium consists mainly of gravel and subordinate sand. In the center-western sectors of the aquifer, some discontinuous silt-clay intercalations appear which give to the aquifer a multilayered character. The depth of the basin increases from east to west (Fig. 2) as shown by the increase of thickness of both gravelly aquifer medium (from 5-10 to $180-200 \mathrm{~m}$ ) and its silt-clay cover (from 3-5 to 30-40 m) [1].

Most of researchers think that River Mat represents the main recharge source for the alluvial aquifer of Fushë Kuqe [2]. The contribution of precipitations and eastern karst aquifers to Fushë Kuqe aquifer are less 


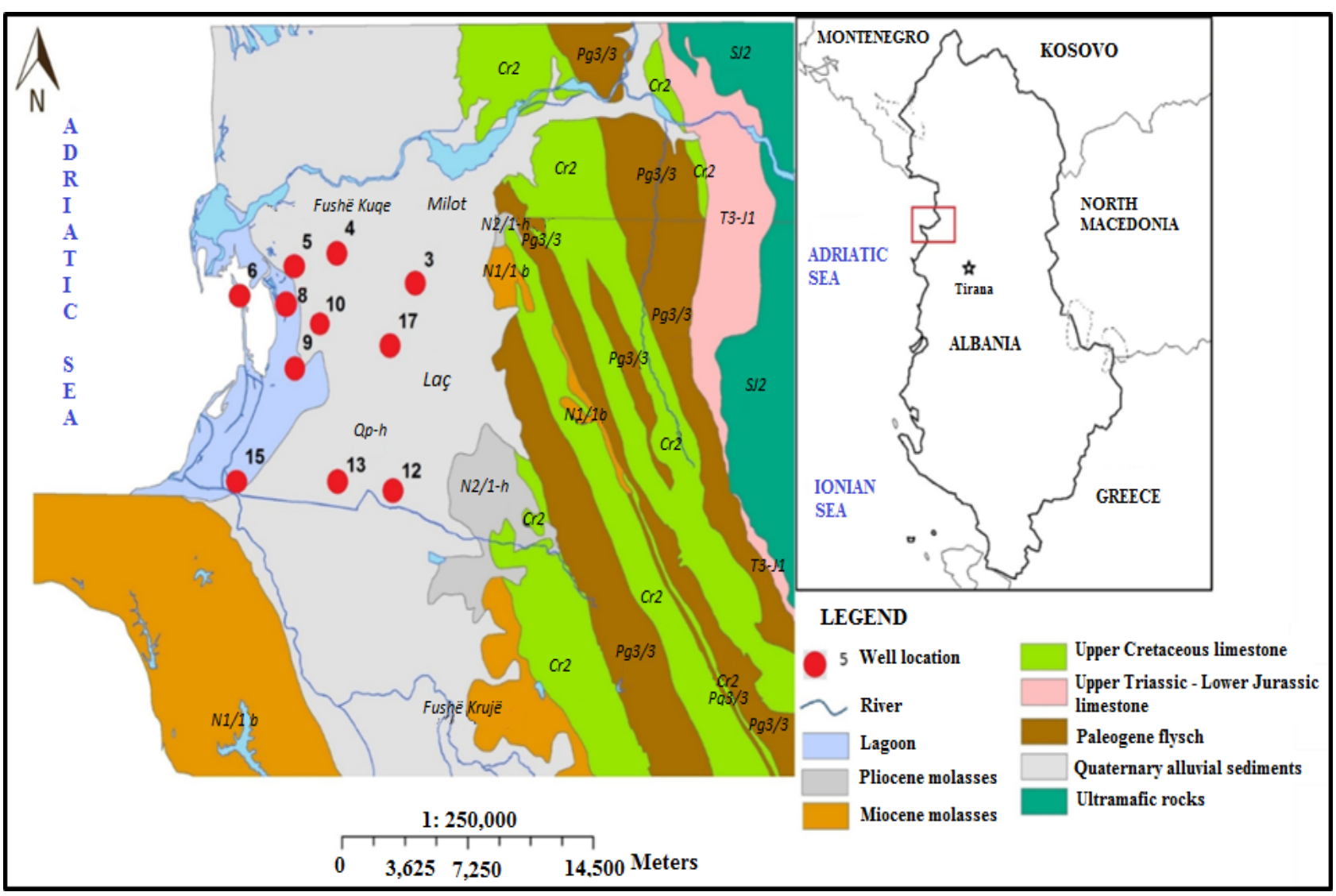

Fig. 1 Geological map of the Fushë Kuqe area (location of water samples is shown).

important, due to the impermeable sandy clay layer on the top of the aquifer and lateral conditions mostly represented by the flysch aquiclude formations, respectively. The direction of groundwater flow is from $\mathrm{NE}$ to $\mathrm{SW}$ and the groundwater discharges to the Adriatic Sea.

The piezometric head varies from about $0 \mathrm{~m}$ a.s.l. at the outlet of the river into the plain to about $3 \mathrm{~m}$ a.s.l. in the littoral, where the aquifer is confined [2]. Near the recharge area, i.e. north-eastern part of the aquifer, it appears as an individual semi-confined aquifer which changes towards the discharge zone to a multilayer confined one due to discontinuous clay intercalations with gravel.

The transmissibility of the aquifer is generally high; in the central part of the plain on both sides of River Mat it is about 4,000 to $8,000 \mathrm{~m}^{2} / \mathrm{d}$, and gradually decreases to about $500-1,000 \mathrm{~m}^{2} / \mathrm{d}$ at the northern and at the southern periphery of the aquifer [3].

\section{Results and Discussion}

\subsection{Sea Water Intrusion}

The alluvial Fushë Kuqe aquifer is also under the pressure of the sea water intrusion along its coastal western line. The alluvial Fushë Kuqe aquifer is also under the pressure of the sea water intrusion along its coastal western line. Based on some preliminary hydrochemical and isotopic (H-2 and O-18) data, authors aim to present some indications on the presence of salt water along the western area of aquifer probably related with sea water intrusion. Due to multilayer character of the aquifer in the coastal area, the groundwater shows different chloride concentration according to the depth of gravel layer. According to Refs. [3, 6], the chloride concentration in the first aquifer layer (up to $50 \mathrm{~m}$ deep) and in the second aquifer layer (up to $90 \mathrm{~m}$ deep) of Adriatic sectors was $152.3 \mathrm{mg} / \mathrm{L}$ and $309.9 \mathrm{mg} / \mathrm{L}$, respectively. In general, 
chloride concentrations over $100 \mathrm{mg} / \mathrm{L}$ are considered indicative of sea water intrusion [3, 13]. Chloride concentrations over $100 \mathrm{mg} / \mathrm{L}$ along entire nearest coastal line are also reported by Ref. [2] who distinguished a southwest-northeast orienting wedge having chloride concentration over $500 \mathrm{mg} / \mathrm{L}$.

In fact, the same findings are confirmed by authors' data where sample No. 6, 8, 9 and 10 (Fig. 1) have chloride concentrations over $100 \mathrm{mg} / \mathrm{L}$. In addition, groundwater of samples No. 6, 8, 9 has $\mathrm{Na} / \mathrm{Cl}$ ratios less than 0.86 implying that the groundwater is contaminated by saline water mixing $[14,15]$ due to sea water intrusion [13]. The points of the above samples fall within the Sea Water field of the Chadha's classification diagram of the Fushë Kuqe groundwater hydrochemical composition [16]. The groundwater of sample No. 8 and 10 that have Simpson Ratio (SR $=$ $\left.\mathrm{Cl} /\left(\mathrm{HCO}_{3}+\mathrm{CO}_{3}\right)\right)$ values of 1.15 and 1.09 is slightly contaminated by sea water, being in accordance with Ref. [6], who evidenced that the upper aquifer layer suffered slight seawater influence. On the other hand, groundwater of sample No. 6 and 9 has SR values of 6.02 and 12.35 which characterize them as injuriously and highly contaminated, respectively.

All the aquifer groundwater sample points fall above the GMWL (Global Meteoric Water Line) (Fig. 2), implying that they have suffered an evaporation before entering the aquifer. This can be explained with the fact that River Mat water before entering into the aquifer is gathered in two hydropower lakes (Lake Ulza and Shkopet) upstream the River Mat course, where they have suffered a considerable evaporation which, in turn, brought to an isotopic enrichment of oxygen and hydrogen. In the enlarged version of Fig. 2, at its down right side, it is shown that most of water points fall close to a straight line as should be expected when all the water samples come from the same watershed. Any deviation from this trend, as indicated by the isotopic depletion of a few water points, may be explained with mixture of River Mat water with River Fan water. In fact, River Fan flow that joins River Mat course about $7.0 \mathrm{~km}$ east-northeast of its outlet into the Milot plain, has a deep narrow valley and a higher watershed, which determines a low evaporation grade of the meteoric water and, consequently was reflected to a respective isotopic depletion.

The $\delta^{18} \mathrm{O}$ and $\delta^{2} \mathrm{H}$ values for the groundwater ranges within narrow (Table 1; Fig. 2) range, that is, from 7.94 to $-6.81 \%$ and from -50.8 to to $41.6 \%$, for oxygen and hydrogen isotopes, respectively. In addition, most of groundwater samples do not indicate any correlation between $\delta^{2} \mathrm{H}$ values and chloride concentrations (Fig. 3) as could be expected in the case of the lack of any fresh water-salt water mixing.

In contrast with Ref. [12], who reported that there is no any relation between $\delta^{18} \mathrm{O}$ and chloride concentrations,

Table $1 \quad \delta^{2} \mathrm{H}$ and $\delta^{18} \mathrm{O}$ values and TDS and $\mathrm{Cl}^{-}$contents of groundwater samples.

\begin{tabular}{lllll}
\hline No. sample & O-18 (V-SMOW) & H-2 (D) (V-SMOW) & TDS $(\mathrm{mg} / \mathrm{L})$ & $\mathrm{Cl}^{-}(\mathrm{mg} / \mathrm{L})$ \\
\hline 3 & -7.38 & -47.5 & 310.71 & 5.41 \\
4 & -7.72 & -49.7 & 234.12 & 4.90 \\
5 & -7.63 & -49.0 & 260.46 & 12.59 \\
6 & -7.38 & -46.8 & $1,289.32$ & 605.60 \\
7 & 1.25 & 6.7 & $36,298.91$ & $22,808.75$ \\
8 & -7.94 & -50.8 & 460.46 & 120.14 \\
9 & -7.14 & -44.7 & $2,204.03$ & $1,138.88$ \\
10 & -7.69 & -48.7 & 511.57 & 128.05 \\
12 & -6.84 & -42.3 & 589.86 & 7.96 \\
13 & -6.81 & -41.6 & 668.41 & 17.11 \\
15 & -7.41 & -46.6 & $2,882.47$ & 173.24 \\
17 & -7.60 & -50.0 & 407.60 & 26.71 \\
\hline
\end{tabular}

(Values of $\mathrm{O}-18=1.25$ and $\mathrm{H}-2=6.7$ belong to Adriatic Sea). 


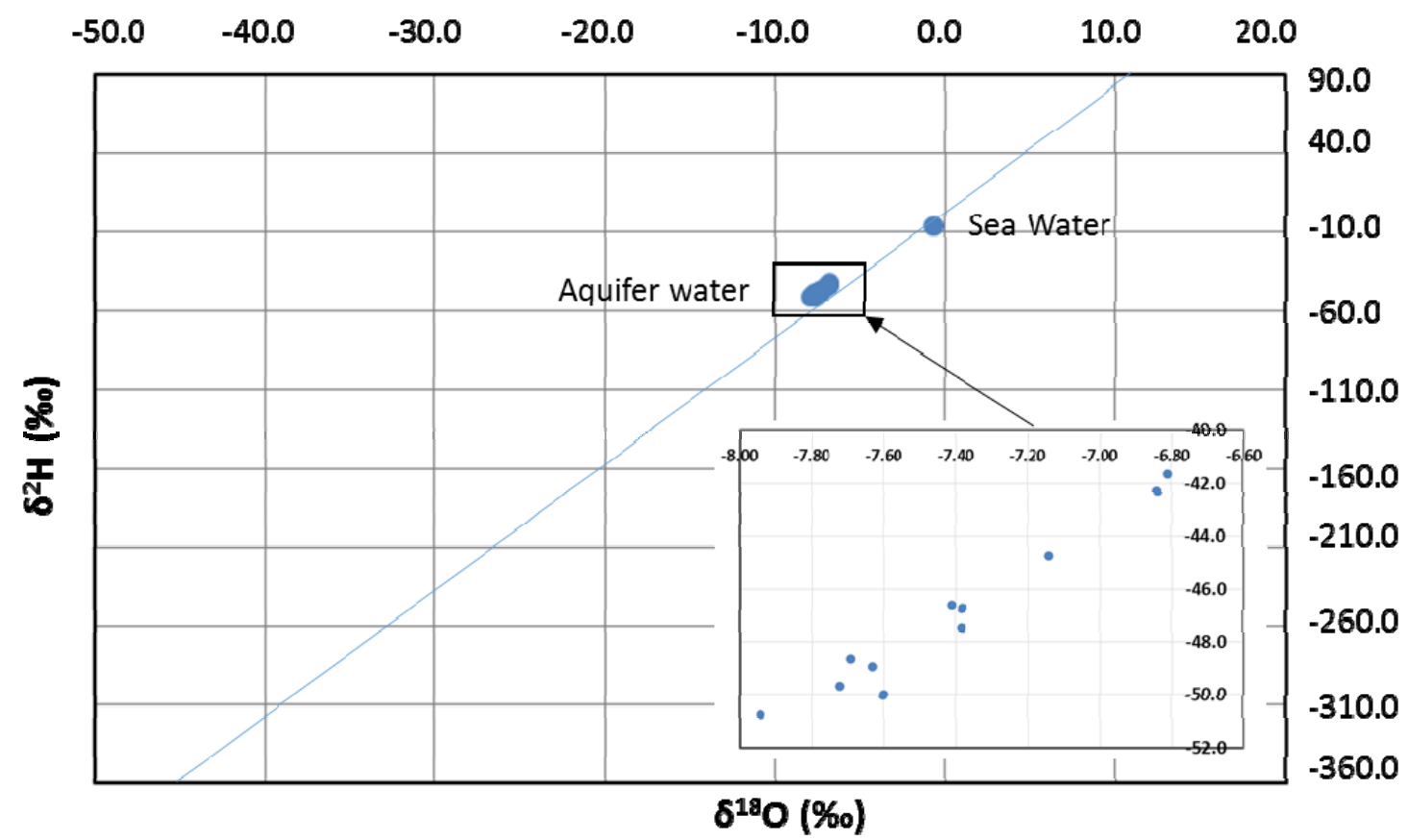

Fig. 2 Isotopic composition of sampled waters confronted with Global Meteoric Waters.

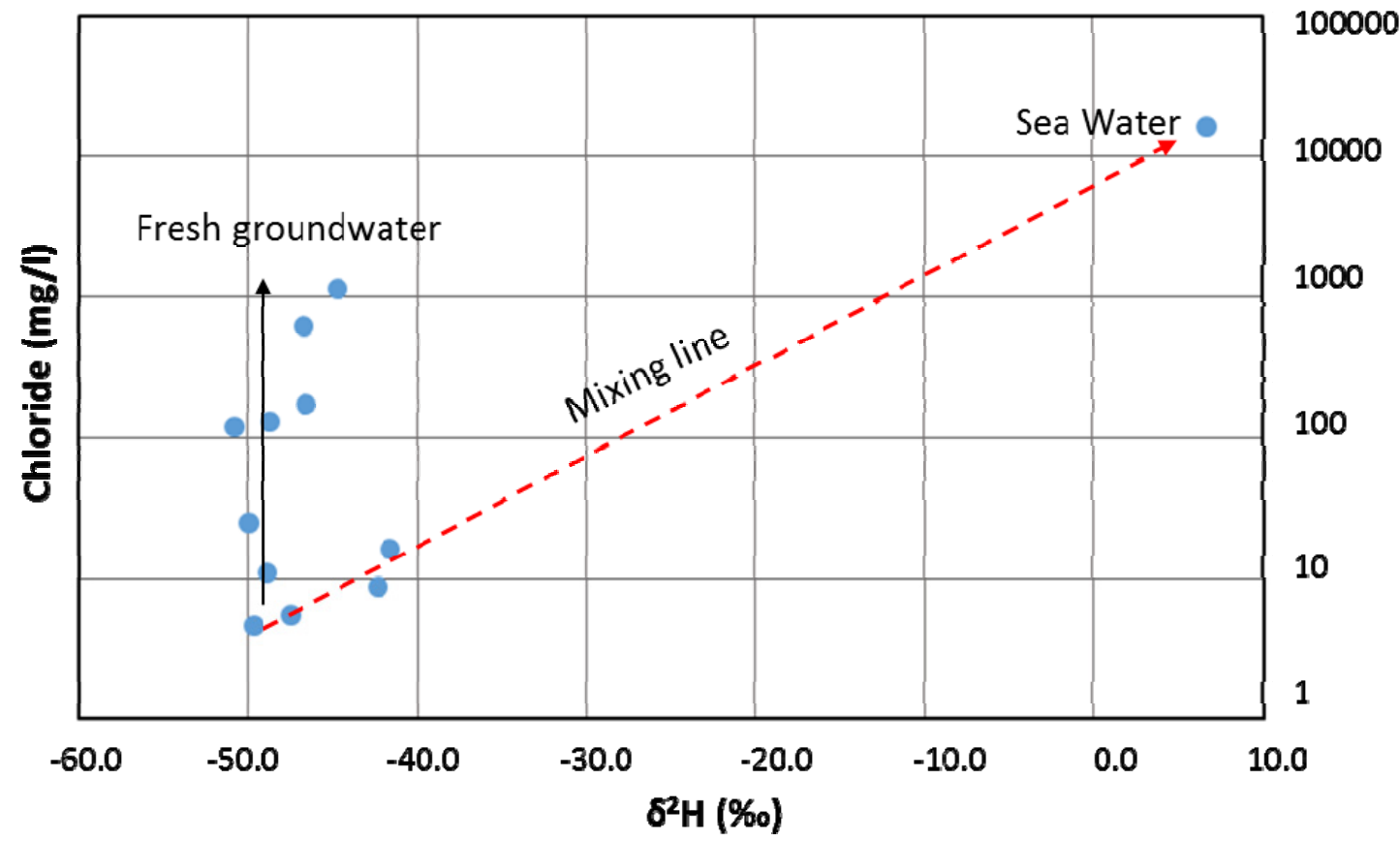

Fig. $3 \delta^{2} \mathbf{H}$ versus chloride concentration in groundwaters.

in Fig. 3, it might be seen that the points of sample No. $6,8,9,10$ fall on the fresh water-seawater mixing line, indicating that the groundwater of these coastal wells is under the influence of the seawater intrusion. Nevertheless of a lack of a continuous monitoring of chloride concentration in groundwater from coastal, an temporal advance of seawater towards the aquifer is reported by Ref. [9] who confronted chloride content in groundwater in well No. 6 and 10, measured in the years 1984, 1999 and 2017. 


\section{Conclusions}

The Fushë Kuqe coastal aquifer is a typical artesian alluvial aquifer that shows high- and low-medium hydraulic parameters in northeastern and southwestern areas of its extension, respectively.

Sample No. 6, 8, 9 and 10 from coastal wells have chloride concentrations over $100 \mathrm{mg} / \mathrm{L}$ and $\mathrm{Na} / \mathrm{Cl}$ ratios less than 0.86 giving indications of sea water intrusion.

SR allows distinguishing groundwater that is slightly influenced by seawater (sample No. 8 and 10, RS = 1.15 and 1.09) from highly contaminated ones (sample No. 6 and $9 \mathrm{SR}=6.02$ and 12.35).

All sampled groundwater has suffered a preliminary evaporation before entering the aquifer, shown by their isotopic enrichment against the GMWL.

The points of sample No. 6, 8, 9, 10 fall on the fresh water-seawater mixing line, indicating the influence of the seawater intrusion to groundwater of the coastal aquifer area.

\section{References}

[1] Eftimi, R., Kolaneci, M., and Tafilaj, I. 1999. "Groundwater Resource Management of Erzen-Ishmi River Basin.” Albanian Journal of Natural Technical Sciences 7: 131-47.

[2] Tartari, M., 2001. Vlerësimi dhe mundësia e rritjes së rezervave të shfrytëzueshme të ujërave nëntokësore në pellgun Tiranë-Lezhë. SHGJSH. Tiranë, Albania. (in Albanian)

[3] Eftimi, R. 2003. "Some Considerations on Seawater-Freshwater Relationship in Albanian Coastal Area." In Proceedings of the Conference: Coastal Aquifers Intrusion Technology: Mediterranean Countries, edited by J. A. López-Geta, J. de Dios Gómez, J. A. de la Orden, G. Ramos and L. Rodriguez. Tome II, IGME Madrid, Alikante, Spain, pp. 239-50.

[4] Diogo, T., Bolster, A., Daniel, M. , Tartakovsky, A., and Marco, D. 2007. "Analytical Models of Contaminant
Transport in Coastal Aquifers." Advances in Water Resources 30 (9): 1962-72.

[5] Eftimi, R. 1966. "Hydrogeology of Mat River Plain." Permbledhje Studimesh 4: 53-65. (in Albanian)

[6] Eftimi, R. 2000. "Water supply of Fushe Kuqe Commune. Hydrogeology of Fushë Kuqe Plain.” ITA Consult.

[7] Eftimi, R., and Stichler, V. 2001. Artificial Tracers to Study Complex Hydrogeological Ecosystems. Tirana Basin. IAEA, Project: ALB/8/009.

[8] Beqiraj, A., Masi, U., and Barbieri, M. 2002. "Caratteristiche geochimiche ed isotopiche di acque sotterranee del bacino idrogeologico di Tirana-Fushë Kuqe ed implicazioni per la Qualita." Special edition, Elbasan, Albania, 48-9. (in Italian)

[9] Cenameri S., and Beqiraj A. 2016. "Assessment of Seawater Intrusion in Fushë Kuqe Aquifer, Albania." Bulletin of the Geological Society of Greece L (2): 665-70.

[10] Marku, S., Kumanova, X., and Jacks, G. 2010. "Threats to a Coastal Aquifer in Northern Albania." In Proceeding of XXXVIII IAH Congress: Groundwater Quality Sustainability, Krakow. University of Silesia Press, 1048-53.

[11] Jacks, G., Kumanova, X., and Marku, S., 2013. "Isotopic Assessment of the Recharge of a Coastal Aquifer in N. Albania." Geophysical Research Abstracts 15: EGU2013-4586.

[12] Kumanova, X., Marku, S., Fröjdö, S., and Jacks, G. 2014. "Recharge and Sustainability of a Coastal Aquifer in Northern Albania." Hydrogeology Journal 22 (4): 883-92.

[13] Lyles, J. R. 2000. "Is Seawater Intrusion Affecting Ground Water on Lopez Island, Washington?" USGS Numbered Series, U.S. Geological Survey, Fact Sheet FS-057-00.

[14] Vengosh, A., Rosenthal, A. 1994. "Saline Groundwater in Israel: It's Bearing on the Water Crisis in the Country." $J$. Hydrol. 156 (1-4): 389-430.

[15] Indu, S. N., Rajaveni, S. P., Schneider, M., and Elango, L. 2015. "Geochemical and Isotopic Signatures for the Identification of Seawater Intrusion in an Alluvial Aquifer." Earth Syst. Sci. 124 (6): 1281-91.

[16] Cenameri, S., and Beqiraj, A. 2019. "Groundwater Geochemistry of the Fushë Kuqe Aquifer, North-Western Albania." Journal of Environmental Science and Engineering B 7: 354-360. 